\title{
The Effect of Good Corporate Governance Principles on the Performance of Micro Finance Banks (BPR) In Serang Regency
}

\author{
Rani Puspa ${ }^{1}$, Dini Martinda Lestari ${ }^{2}$, Angrian Permana ${ }^{3}$ \\ ${ }^{1,3}$ Management Departement, Bina Bangsa University, Serang, Indonesia \\ ${ }^{2}$ Accounting Departement, Bina Bangsa University, Serang, Indonesia
}

\begin{abstract}
Transparency, accountability, responsibility, independence and fairness are basic principles of GCG implementation. This study used a questionnaire technique survey method distributed to 37 BPRs. The sample used was 74, each having received two respondents from each BPR in the Financial Section and Serang Regency General Section. Sample determination using purposeful sampling. The analytical technique is a simple linear regression analysis using SPSS. This study shows that applying the principles of good corporate governance that include transparency, accountability, accountability, independence, and fairness has a positive effect on the performance of Serang Regency Micro Finance Banks.
\end{abstract}

Keyword: good corporate governance, Micro Finance Banks, performance, serang.

\section{INTRODUCTION}

Cerang Regency is noted to have the largest number of BPRs $\checkmark$ in Banten, so the potential for providing credit to the community is quite high. This requires BPRs to improve their business performance. The number of BPRs spread across Banten according to the Financial Services Authority (OJK) in 2018 was 137 BPRs, of which 49 BPRs are located in Serang Regency, based on GRDP data, the growth rate of Serang Regency at constant prices which continued to increase in 2011 by $1.75 \%$ and in 2012 amounted to $2.94 \%$ (www.Serangkab.bps.go.id). The data obtained shows that good performance is not an easy thing, it requires the application of a good system and effective supervision. According to (Pratiwi 2014), the performance of a bank must be able to be measured and describe the condition of the company at that time, for that it is necessary to evaluate and measure the performance of the company. The Bank Indonesia version of performance measurement refers to the elements of Capital, Asset Quality, Management Earning Liquidity (CAMEL). CAMEL is used to measure the financial performance of its operational activities with a predetermined percentage level so that the bank soundness level can be found in the form of a composite improvement [1].

Measuring company performance based solely on financial terms such as the amount of profit earned is sometimes not very suitable. Therefore, to assess the performance of companies in the banking sector, many approaches are needed besides the financial approach, namely the non- financial approach that can be applied in the banking sector [2]. Based on this aspect, it refers to the appropriate performance measurement system used, especially in today's competitive banking world, which is a balanced scorecardbased performance measurement designed by Robert $\mathrm{S}$. Kaplan and David P. Norton [3]. Khozein (2012) states that the balanced scorecard is unique in terms of its comprehensive measurement by assessing performance from four perspectives, namely financial perspective, customer perspective, internal business process perspective, and learning and growth perspective [4]. The use of a balanced scorecard can help the company's operations in the long run. This is because the use of a balanced scorecard can measure performance both from a financial and non-financial perspective [3].

The current phenomenon is a change in the structure of life, especially in the economic field. Companies need to consider all aspects in order to maintain company consistency. The separation of functions between the owner (principal) and manager (agent) is a cause of conflict of interest [5]. The company manager who is entrusted to the manager appointed by the shareholders, in reality there is often a cross between the two parties' goals. Managers can sacrifice the interests of shareholders with the power they have to act in their own favor. Shareholders (principal) are more interested in what has been achieved by management (agent) where they expect good news from the investment they have invested in the company, on the other hand the management will try to increase their interests in order to get a high bonus by trying to provide good impression so that it is always trusted by the shareholders (principal) and obtains the expected benefits. Agency theory explains that to overcome this problem it is necessary to pay attention to the weak application of a corporate governance system known as Good Corporate Governance (GCG)[6].

Several cases that occurred in 2014, a large People's Credit Bank company in the Semarang area, Central Java, named BPR Restu Artha Makmur, was suspected of having committed acts of falsifying credit data to the detriment of customer assets (financial.bisnis.com). In 2019 the Financial Services Authority (OJK) again revoked the business license of the People's Credit Bank (BPR) Legian which is located in 
Denpasar. The revocation of the BPR business license occurred due to management problems that did not refer to the principles of prudence and good governance as well as the negative intervention of controlling shareholders in bank operations which resulted in the BPR's financial performance not meeting the set standards (www.cnbcindonesia.com ). Not long after, in 2019, August 13, there was another revocation of the business license of PT Bank Perkreditan Rakyat Calliste Bestari in Mengwi-Serang. The Head of the Regional OJK Office also revealed that the cause of BPR Calliste Bestari was problematic due to unhealthy banking practices, both by management and shareholders (www.cnbcindonesia.com). The banking fraud case disclosed in Kompas.com was the conspiracy of fraudulent investment / deposit worth Rp. 111 billion for the personal benefit of the Head of Bank Mega Jababeka Branch and the Finance Director of PT Elnusa Tbk in 2011. Elnusa's management emphasized that the search for time deposit funds was only done once at a time. March 5, 2010. The search was valued at Rp. 50 billion of the total deposits of Rp. 161 billion. The remaining deposit is $\mathrm{Rp}$. The 111 billion was allegedly disbursed in a manner that was not in accordance with applicable banking procedures and without the approval of management. This fraud caused huge losses to PT Elnusa and Bank Mega [7].

Seeing the rampant cases that have occurred in Bank Perkreditan Rakyat (BPR), Good Corporate Governance is currently needed to mitigate or reduce the level of fraud in BPR cases, the International Monetary Find (IMF) introduced the concept of GCG as a healthy corporate governance procedure [8]. According to the KNKG which was formed in 1999 based on the Coordinating Minister for Economic Affairs Decree Number: KEP / 31 / M.EKUIN / 08/1999, it has issued Good Corporate Governance guidelines. These guidelines have been refined several times, most recently in 2006 by the KNKG (National Committee for Governance Policy). Good Corporate Governance is a Bank governance that applies the principles of transparency, accountability, responsibility, independency, and fairness. These principles are expected to produce more optimal decisions and if good corporate governance, it shows a tendency for greater corporate responsibility [9]. The Indonesian Institute of Corporate Governance Good Corporate Governance has the aim of improving the company's image in the eyes of the public, attracting investors, as a demand in global competition, minimizing the costs of abuse of authority in companies and minimizing risks arising from poor corporate governance [10].

\section{RELATED WORK}

Good implementation of Good Corporate Governance is a concept that emphasizes the importance of shareholders' rights to obtain correct, accurate, and timely information. In addition, it also shows the company's obligation to disclose all financial performance information in an accurate, timely and transparent manner. Therefore, both public and private companies must view good corporate governance (GCG) not as mere accessories but also as an effort to improve company performance and value. A good corporate governance is designed to overcome deficiencies in the corporate governance system and to improve the quality of corporate governance as a whole.

The Organization for Economic Co-operation and Development (OECD) revealed that the benefits of GCG include smoothing the decision-making process, increasing efficiency and creating a healthier work culture so that company performance will increase. Various studies were conducted to determine the relationship between GCG and banking performance. As research conducted by [11] suggests that GCG practices increase company transparency, ensure accountability and increase profitability, the general result is that GCG has an influence on company performance [11].

The results of research from [12] suggest that there is a relationship between corporate governance and banking performance. The failure of corporate governance will also lead to failure in financial performance [12]. The application of GCG principles has an effect on BPR performance [8]. Based on the results of previous research, it can be concluded that the implementation of GCG has an effect on banking performance. Referring to the results of previous studies, the better the implementation of GCG, the better the bank's performance.

Transparency is providing information openly and honestly to stakeholders based on the consideration that stakeholders have the right to know openly and thoroughly the responsibility of the company in managing the resources entrusted to it. Openness in disclosing information about the company will increase stakeholder confidence in the company, so that the company's performance is expected to be better. Research conducted by Dewi \& Dwijaputri, (2014) that the principles of good corporate governance have a positive effect on performance [8]. Rahmandy (2012) conducted research on the application of the principles of Good Corporate Governance (GCG) at PT Bank Tabungan Negara (Persero) Tbk, saying that the application of GCG principles would improve company performance [1]. The same thing is also explained in Pratiwi \& Setiawan's (2014) research, transparency has a positive effect on performance. In accordance with agency theory, this shows that the more transparent BPRs are in disclosing information about the condition of BPRs, an increase in principals 'trust, the more BPRs' performance will increase [6]. Based on this description, the formulation of the first hypothesis in this study is as follows.

$H_{1}$ : Transparency has a positive effect on the performance of Rural Banks in Serang Regency.

Accountability is the company's responsibility for performance in a transparent and fair manner to stakeholders. For this reason, the company must be managed properly, measured and in accordance with the interests of the company while taking 
into account the interests of stakeholders, which in turn will improve the company. Based on research conducted by [13], the principle of accountability has a positive effect on the financial performance of the Denpasar City LPD [13]. This is in line with the results of research conducted by [4] which found that accountability has a positive effect on LPD financial performance [4].

In accordance with agency theory, this shows that the clearer the authority and function of the implementation and accountability of the organizational structure in the BPR, the management of the BPR will be carried out effectively and increase the trust of the principals, which in turn will improve the performance of the BPR. Based on this description, the formulation of the second hypothesis in this study is as follows.

$\mathrm{H}_{2}$ : Accountability has a positive effect on the performance of Rural Banks in Serang Regency.

Responsibility is a company's attitude in managing its business based on the prevailing laws and regulations. To improve its performance, companies must understand and comply with regulations and carry out responsibilities towards stakeholders so that business continuity can be maintained in the long term. Research conducted by Sawitri (2017) found that responsibility has a positive effect on the performance of Rural Banks (BPRs) in Denpasar City. The same thing was also found in research conducted by [6] that the results of the responsibility of good corporate governance on performance based on the Balanced Scorecard have a positive effect on the financial performance of LPDs in Denpasar City. In accordance with agency theory, this shows that complying with all existing regulations and carrying out responsibilities towards principals can have an impact on the growth of BPRs which have an impact on improving BPR performance. Based on this description, the formulation of the third hypothesis in this study is as follows.

$H_{3}$ : Responsibility has a positive effect on the performance of Rural Banks in Serang Regency.

Independence is the company's attitude in making decisions without being tied to any party or party that dominates. To improve its performance, the company must act objectively or free from the interests of those who harm the company. Research conducted by [10] found that independence has a positive effect on the financial performance of LPDs in Abiansemal sub-district, Serang Regency. The same thing was also found in research conducted by [7] which found that independence had a positive effect on the implementation of independence on performance.

In accordance with agency theory, this shows that in the absence of a conflict of interest in BPR management, it can have an impact on increasing the trust of the BPR principals and performance and ensuring that the BPR is objective in its management. Based on this description, the formulation of the fourth hypothesis in this study is as follows.
$H_{4}$ : Independence has a positive effect on the performance of Rural Banks in Serang Regency.

Fairness is the fairness and equality of the company in meeting the interests of stakeholders that arise based on agreements and applicable laws and regulations. Companies must always pay attention to the rights of stakeholders based on the principles of fairness and equality in order to improve company performance in a good direction. Based on research by [8] states that fairness has a positive influence on the financial performance of LPDs in Gianyar Regency. This is in line with research conducted by [14] which found that the principle of fairness has a positive effect on the performance of the People's Credit Bank in Gianyar Regency.

In accordance with agency theory, this shows that if BPR managers pay attention to the rights of the principals and treat them fairly based on the principles of fairness and equality, it can improve BPR performance. Based on this description, the formulation of the fifth hypothesis in this study is as follows.

$\mathrm{H}_{5}$ : Fairness has a positive effect on the performance of Rural Banks in Serang Regency.

\section{RESEARCH METHODS}

This research was carried out on all BPRs in the Serang Regency area, by accessing the www.ojk.go.id page to obtain information regarding BPRs in the Serang area. The object of this research is the performance based on the balanced scorecard at the Rural Bank (BPR) in Serang Regency and the influence of Good Corporate Governance on the performance based on the Balance Scorecard.

The population in this study were rural banks (BPR) in the Serang area. This location was chosen because the People's Credit Bank in Serang Regency was listed as the BPR that had the first largest number in Banten, so the potential for providing credit to the community was quite high. The following is the amount of BPR data obtained from the Financial Services Authority in Serang Regency. The method used in this research is purposive sampling method, in which the sample is determined with certain considerations in accordance with the specified staff.

Respondents selected in this study were the staff of Bank Perkeditan Rakyat (BPR). Financial staff and general staff were selected as respondents because their operational activities are closest to the implementation of GCG, where financial staff provides assurance on the quality of financial information by providing an independent opinion on the fairness of the presentation of information in the financial statements. Meanwhile, the general staff has a better understanding of the procedures in the workplace, because it is related to all other staff. A sample of 74, each BPR consists of 2 respondents, namely financial staff and general staff.

The data analysis tools used were the coefficient of determination $\mathrm{R}^{2}$, the $\mathrm{F}$ test (model feasibility), the $\mathrm{t}$ 
statistical test (the significance test for individual parameters) which aims to test the hypothesis using multiple linear regression through the SPSS computer program with the following formula.

$$
\mathrm{Y}=\square+\beta_{1} X_{1}+\beta_{2} X_{2}+\beta_{3} X_{3}+\beta_{4} X_{4}+\beta_{5} X_{5}
$$

Information :

$\begin{array}{ll}\mathrm{Y} & =\text { Dependence Variable (Performance) } \\ & =\text { Constanta } \\ \beta_{1} \beta_{2} \beta_{3} \beta_{4} \beta_{5} & =\text { Coefficient Regression for } \mathrm{X}_{1}, \mathrm{X}_{2}, \mathrm{X}_{3} \\ \mathrm{X}_{4}, \mathrm{X}_{5} & \\ \mathrm{X}_{1} & =\text { Transparency } \\ \mathrm{X}_{2} & =\text { Accountability } \\ \mathrm{X}_{3} & =\text { Responsibility } \\ \mathrm{X}_{4} & =\text { Independency } \\ \mathrm{X}_{5} & =\text { Fairness }\end{array}$

To complete this data analysis as a whole, the SPSS program was used and all the results of the resulting data output were interpreted one by one including determining the correlation coefficient $(\mathrm{R})$ to measure the level of relationship between the independent variable and the dependent variable and the coefficient of determination $\left(\mathrm{R}^{2}\right)$ to measure the effect. Between the independent variable and the dependent variable.

\section{RESULTS AND DISCUSSION}

Descriptive statistics provide information about the characteristics of the variables studied. Descriptive statistics show information about the number of observations, the minimum value, the maximum value, the mean value, and the standard deviation.

Based on Table 1, it can be obtained that the minimum value of the total score of respondents' answers for the transparency variable is 2.00 and the maximum value is 4.00 . The average value of 3.2601 indicates that the respondents tend to agree on each statement item in the questionnaire. The standard deviation is 0.61299, which means that the standard deviation value is smaller than the average value.

Based on Table 1, the minimum value of the total score of respondents' answers for the accountability variable is 2.00 and the maximum value is 4.00 . The average value of 3.2838 indicates that the respondents tend to agree on each statement item in the questionnaire. The standard deviation is 0.56180 , it means that the standard deviation value is smaller than the average value. Table 1, below presents the results of descriptive statistics.
Table 1. Descriptive Test Results

\begin{tabular}{|c|c|c|c|c|c|}
\hline & $\mathrm{N}$ & Minimum & Maximum & Mean & $\begin{array}{c}\text { Std. } \\
\text { Deviation }\end{array}$ \\
\hline Transparency & 74 & 2,00 & 4,00 & 3,2601 & 0,61299 \\
\hline Accountability & 74 & 2,00 & 4,00 & 3,2838 & 0,56180 \\
\hline Responsibilities & 74 & 2,25 & 4,00 & 3,2601 & 0,54810 \\
\hline Independency & 74 & 2,00 & 4,00 & 3,1565 & 0,63497 \\
\hline Fairness & 74 & 2,00 & 4,00 & 3,2196 & 0,62339 \\
\hline $\begin{array}{c}\text { Company } \\
\text { Performance }\end{array}$ & 74 & 2,00 & 4,00 & 3,3576 & 0,55800 \\
\hline Valid N (listwise) & 74 & & & & \\
\hline
\end{tabular}

Source: Research Data, 2020

Based on Table 1, it can be obtained that the minimum value from the total score of respondents' answers for the responsibility variable is 2.25 and the maximum value is 4.00 . The average value of 3.2601 shows that respondents tend to feel agree with each statement item in the questionnaire. The standard deviation is 0.54810 , which means that the standard deviation value is smaller than the average value.

Based on Table 1, it can be obtained that the minimum value of the total score of respondents' answers for the independence variable is 2.00 and the maximum value is 4.00 . The average value of 3.1565 indicates that respondents tend to agree on each statement item in the questionnaire. The standard deviation is 0.63497 , meaning that the standard deviation value is smaller than the average value.

Based on Table 1, it can be obtained that the minimum value of the total score of respondents' answers for the fairness variable is 2.00 and the maximum value is 4.00 . The average value of 3.2196 indicates that the respondents tend to agree on each statement item in the questionnaire. The standard deviation is 0.62339 , meaning that the standard deviation value is smaller than the average value.

Based on Table 1, it can be obtained that the minimum value of the total score of respondents' answers for the company performance variable is 2.00 and the maximum value is 4.00 . The average value of 3.3576 shows that the respondents tend to agree on each of the statement items in the questionnaire. The standard deviation is 055800 , meaning that the standard deviation value is smaller than the average value.

A constant value of 2.283 states that if the variables of transparency (X1), accountability (X2), responsibility (X3), independence (X4) and fairness (X5) are equal to zero, then the performance of the BPR in Serang Regency (Y) is 2.283 units.

The regression coefficient value of transparency (X1), amounting to 0.652 indicates that there is a positive influence between the transparency variable on the performance of BPR in Serang Regency of 0.652. This means that if the independent variable transparency increases by 1 unit with the assumption that the other independent variables are constant, 
then the BPR performance variable in Serang Regency will increase by 0.652 .

The regression coefficient value of accountability (X2), amounting to 0.617 , indicates that there is a positive influence between the accountability variable on the performance of BPR in Serang Regency of 0.617. This means that if the independent variable accountability increases by 1 unit with the assumption that the other independent variables are constant, then the BPR performance variable in Serang Regency will increase by 0.617 . The results of multiple linear regression analysis are presented in Table 2.

Table 2. Results of Multiple Linear Regression Analysis

\begin{tabular}{|c|c|c|c|c|c|}
\hline \multirow{2}{*}{ Model } & \multicolumn{2}{|c|}{$\begin{array}{c}\text { Unstandardized } \\
\text { Coefficients }\end{array}$} & \multicolumn{2}{c|}{$\begin{array}{c}\text { Standardized } \\
\text { Coefficients }\end{array}$} & \\
\cline { 2 - 6 } & $B$ & $\begin{array}{c}\text { Std. } \\
\text { Error }\end{array}$ & Beta & $\mathrm{T}$ & Sig. \\
\hline (Constant) & 2,283 & 3,048 & & 0,749 & 0,457 \\
\hline Transparency & 0,652 & 0,262 & 0,239 & 2,489 & 0,015 \\
\hline Accountability & 0,617 & 0,288 & 0,207 & 2,143 & 0,036 \\
\hline Responsibilities & 0,612 & 0,250 & 0,200 & 2,452 & 0,017 \\
\hline Independency & 0,731 & 0,356 & 0,208 & 2,052 & 0,044 \\
\hline Fairness & 0,504 & 0,238 & 0,187 & 2,114 & 0,038 \\
\hline R & 0,846 & & & & \\
\hline R Square & 0,715 & & & & \\
\hline Adjusted R Square & 0,695 & \multicolumn{5}{|l}{} \\
\hline F Statistic & 34,202 & & & & \\
\hline Significance F-test & 0,000 & \multicolumn{5}{|l}{} \\
\hline
\end{tabular}

Source: Research Data, 2020

Based on Table 2, the regression equation can be arranged as follows.

$\mathrm{Y}=2,283+0,652 \mathrm{X}_{1}+0,617 \mathrm{X}_{2}+0,612 \mathrm{X}_{3}+0,731 \mathrm{X}_{4}+$ $0,504 \mathrm{X}_{5}$

The regression coefficient value of responsibility $\left(\mathrm{X}_{3}\right)$, amounting to 0.612 , shows that there is a positive influence between the responsibility variable on the performance of BPR in Serang Regency of 0.612. This means that if the independent variable responsibility increases by 1 unit, assuming that the other independent variables are constant, then the BPR performance variable in Serang Regency will increase by 0.612 .

The regression coefficient value of independence $\left(X_{4}\right)$, amounting to 0.731 indicates that there is a positive influence between the independence variable on performance

BPR in Serang Regency of 0.731. This means that if the independent independent variable increases by 1 unit, assuming that the other independent variables are constant, then the BPR performance variable in Serang Regency will increase by 0.731 .
The regression coefficient value of fairness $\left(\mathrm{X}_{5}\right)$, amounting to 0.504 , indicates that there is a positive influence between the fairness variable on the performance of BPR in Serang Regency of 0.504 . This means that if the independent variable of fairness increases by 1 unit with the assumption that the other independent variables are constant, then the BPR performance variable in Serang Regency will increase by 0.504 .

The coefficient of determination $\left(\mathrm{R}^{2}\right)$ is used to determine and measure the model's ability to explain variations in the independent variable. Based on Table 2, the Adjust R Square value is 0.695 , this means that 69.5 percent of the variation in BPR performance in Serang Regency $(\mathrm{Y})$ is influenced by the variables of transparency $\left(\mathrm{X}_{1}\right)$, accountability $\left(\mathrm{X}_{2}\right)$, responsibility $\left(\mathrm{X}_{3}\right)$, independence $\left(\mathrm{X}_{4}\right)$ and fairness. $\left(\mathrm{X}_{5}\right)$, the remaining 30.5 percent is influenced by other factors outside the research model.

The correlation coefficient (R) is used to measure the level of the relationship between the independent variable and the dependent variable and the coefficient of determination (R2) to measure the influence between the independent variable and the dependent variable.

Based on the results of the analysis in Table 2, it is obtained that the multiple correlation coefficient is $\mathrm{R}=0.846$. This means that there is a very strong relationship together between the variables of transparency $\left(\mathrm{X}_{1}\right)$, accountability $\left(\mathrm{X}_{2}\right)$, responsibility $\left(\mathrm{X}_{3}\right)$, independence $\left(\mathrm{X}_{4}\right)$ and fairness $\left(\mathrm{X}_{5}\right)$ with the performance of BPR in Serang Regency (Y).

The $\mathrm{F}$ test aims to determine the feasibility of multiple linear regression models as an analysis tool that tests the effect of independent variables on the dependent variable. The results of the $\mathrm{F}$ test can be explained by the $\mathrm{p}$-value. The significance of $F$ is 0.000 less than 0.05 . The results of the $F$ test analyzed using the SPSS program obtained an F value of 34.202 with a significance of $0.000<0.05$, it can be concluded that the group tested had a significant difference. This result means that there is a significant influence between transparency, accountability, responsibility, independence and fairness on the performance of BPR in Serang Regency. Thus, the model is considered worthy of testing and proving the hypothesis can be continued.

Transparency is providing information openly and honestly to stakeholders based on considerations that stakeholders have the right to know openly and thoroughly the responsibility of the company in managing the resources entrusted to it. Based on the test results (t test) in this study, it was found that transparency has a positive regression coefficient value of 0.652 and Sig t $0.015<0.050$. The test results indicate that the first hypothesis $\left(\mathrm{H}_{1}\right)$ transparency has a positive effect on the performance of BPRs in Serang Regency is accepted. This means that the higher the transparency, the higher the BPR performance in Serang District. In connection with agency theory, with the company being able to provide information openly and honestly to stakeholders, it will improve the 
performance of BPR in Serang Regency, on the other hand, if the information provided by the company is not open and accurate to stakeholders, it will reduce the performance of BPR in Serang Regency. This is also supported by the theory of stewardship where the theory describes a situation where managers are not motivated by individual goals but rather aimed at their main outcome goals for the benefit of the organization, so that this theory has a psychological and sociological basis that has been designed in which executives as stewards are motivated to act according to the principal's wishes, so that managers will always prioritize the interests of the company by always giving efforts to provide information openly and honestly to stakeholders to improve performance. These results support research conducted by research conducted by [8] principles of good corporate governance positive effect on performance. Research on the application of the principles of good corporate governance (GCG) at PT Bank Tabungan Negara (Persero) Tbk, saying that the application of GCG principles would improve company performance [7]. The same thing is also presented in research [6], transparency has a positive effect on performance.

Accountability is the company's responsibility for performance in a transparent and fair manner to stakeholders. Based on the test results ( $t$ test) in this study, it was found that accountability has a positive regression coefficient value of 0.617 and Sig t $0.036<0.050$. The test results indicate that the second hypothesis $\left(\mathrm{H}_{2}\right)$ of accountability has a positive effect on the performance of BPRs in Serang Regency is accepted. This means that the higher the accountability, the higher the BPR's performance in Serang Regency. In connection with agency theory, if the company is able to provide accountability for performance transparently and fairly to stakeholders, it will improve the performance of BPR in Serang Regency, on the other hand, if the company is unable to provide accountability for performance transparently and fairly to stakeholders, it will reduce the performance of BPR in Serang Regency. Serang Regency. This is also supported by the theory of stewardship where the theory describes a situation where managers are not motivated by individual goals but rather aimed at their main outcome goals for the benefit of the organization, so that this theory has a psychological and sociological basis that has been designed where executives as stewards are motivated to act according to the principal's wishes, so that managers will always prioritize the interests of the company by always providing accountability for performance in a transparent and fair manner to stakeholders to improve performance

These results support the research conducted by [13], that the principle of accountability has a positive effect on the financial performance of the LPD in Denpasar City. This is in line with the results of research conducted by [4] which found that accountability has a positive effect on LPD financial performance.

Responsibility is the attitude of a company in managing its business based on the prevailing laws and regulations. Based on the results of the test ( $t$ test) in this study, it was found that responsibility has a potential regression coefficient of 0.612 and Sig t $0.017<0.050$. The test results indicate that the third hypothesis $\left(\mathrm{H}_{3}\right)$ responsibility has a positive effect on the performance of BPRs in Serang Regency is accepted. This means that the higher the responsibility, the higher the BPR's performance in Serang Regency. With regard to agency theory, if the company is able to understand and comply with regulations and carry out responsibilities to stakeholders so that business continuity can be maintained in the long term, it will improve the performance of BPRs in Serang Regency, conversely if the company is unable to understand and comply with regulations and carry out responsibility for stakeholders then will reduce the performance of BPR in Serang Regency. provide information openly and honestly to stakeholders. This is also supported by the theory of stewardship where the theory describes a situation where managers are not motivated by individual goals but rather aimed at their main outcome goals for the benefit of the organization, so that this theory has a psychological and sociological basis that has been designed where executives as stewards are motivated to act according to the wishes of the principal, so that managers will always try to understand and comply with the rules and carry out responsibilities towards stakeholder holders to improve performance.

These results support the research conducted by [3], which shows that responsibility has a positive effect on the performance of Rural Banks (BPRs) in Denpasar City. The same thing was also found in the research conducted by [6] that the results of the responsibility of good corporate governance on performance based on the Balanced Scorecard had a positive effect on the financial performance of LPDs in Denpasar City.

Independence is the company's attitude in making decisions without being tied to any party or party that dominates. Based on the test results ( $t$ test) in this study, it was found that independence had a potential regression coefficient of 0.731 and Sig t $0.044<0.050$. The test results indicate that the fourth hypothesis $\left(\mathrm{H}_{4}\right)$ of independence has a positive effect on the performance of BPRs in Serang Regency is accepted. This means that the higher the independence, the higher the BPR's performance in Serang Regency. With regard to agency theory, if the company is able to act objectively or free from the interests of parties that harm the company, it will improve the performance of BPR in Serang Regency, on the other hand, if the company is unable to act objectively or free from the interests of parties that are detrimental to the company, it will reduce performance. BPR in Serang Regency. This is also supported by the theory of stewardship where the theory describes a situation where managers are not motivated by individual goals but rather aimed at their main outcome goals for the benefit of the organization, so that this theory has a psychological and sociological basis that has been designed in which executives as stewards are motivated to act according to the wishes of the principal, so that managers will always act 
objectively or free from the interests of parties that harm the company to improve performance

These results support the research conducted by [12] which shows that independence has a positive effect on the financial performance of LPDs in Abiansemal sub-district, Serang Regency. The same thing was also found in research conducted by [7] which found that independence has a positive effect from the application of independence on performance.

Fairness is the fairness and equality of the company in meeting the interests of stakeholders that arise based on agreements and applicable laws and regulations. Based on the test results ( $t$ test) in this study, it was found that reasonableness has a positive regression coefficient value of 0.504 and Sig t 0.038 $<0.050$. The test results indicate that the fifth hypothesis (H5) of fairness has a positive effect on the performance of BPRs in Serang Regency is accepted. This means that the higher the reasonableness, the higher the BPR performance in Serang Regency. In connection with agency theory, if the company is able to provide justice and equality in meeting the interests of stakeholders, it will improve the performance of BPR in Serang Regency, on the other hand, if the company is unable to provide justice and equality in meeting stakeholder interests, it will reduce the performance of BPR in Serang Regency. This is also supported by the theory of stewardship where the theory describes a situation where managers are not motivated by individual goals but rather aimed at their main outcome goals for the benefit of the organization, so that this theory has a psychological and sociological basis that has been designed in which executives as stewards are motivated to act according to the wishes of the principal, so that managers will always prioritize the interests of the company by always applying justice and equality in fulfilling stakeholder interests to improve performance.

These results support the research conducted [8] which stated that fairness has a positive influence on the financial performance of LPDs in Gianyar Regency. This is in line with the research conducted [14] which found that the principle of fairness has a positive effect on the performance of the People's Credit Bank in Gianyar Regency.

\section{CONCLUSION}

This study provides a broader picture and insight into good corporate governance and obtains a better understanding of agency theory and stewardship theory and its impact on bank performance. More specifically, this research provides a broader understanding of the principles of GCG that affect bank performance. The test results in this study found that statistically transparency, accountability, responsibility, independence and fairness have a positive effect on the performance of rural banks in Serang Regency. This research has implications for BPR in Serang Regency as a consideration and knowledge of performance and the factors that influence it. Companies can evaluate transparency, accountability, responsibility, independence and fairness, because these can affect the performance of BPRs in Serang Regency.

\section{REFERENCESS}

[1] I. B. \&. S. I. D. G. D. Brahmananda, " Analisis Komparatif Tingkat Kesehatan Bank Antara CAMELS dan RGEC PT Bank BPD Bali Tahun 2012- 2014.,," Jurnal Akuntansi Universitas Udayana, vol. 19, no. 1, pp. 51-80, 2017.

[2] D. T. W. \&. P. E. Fitriyani, "Good Corporate Governance Dan Dampaknya Terhadap Kinerja Berdasarkan Balanced Scorecard.," Jurnal Akuntansi, vol. 20, no. 3, p. 91-103, 2017.

[3] P. a. D. A. Andriyani, "Pengaruh Good Corporate Governance Pada Kinerja Berbasis Balanced Scorecard," EJurnal Akuntansi, vol. 15, no. 2, p. 832-846., 2016.

[4] Khrisna, "Pengaruh Prinsip-Prinsip Good Corporate Governance Terhadap Kinerja Keuangan Lembaga Perkreditan Desa (LPD) Di Kota Denpasar.," E- Jurnal Akuntansi Universitas Udayana, vol. 21, no. 2, p. 970-995, 2017.

[5] E. D. \&. C. B. Araujo, "Confirmatory factor analysis on strategic leadership, corporate culture, good corporate governance and company performance.," Social Sciences and Humanities , vol. 4, no. 4, p. 487-495., 2013.

[6] I. \&. S. P. Pratiwi, "Pengaruh Kesadaran Wajib Pajak, Kualitas Pelayanan, Kondisi Keuangan Perusahaan, Dan Persepsi Tentang Sanksi Perpajakan Pada Kepatuhan Wajib Pajak Reklame Di Dinas Pendapatan Kota Denpasar.," EJurnal Akuntansi, vol. 6, no. 1, p. 139-153, 2014.

[7] N. \&. A. R. Rahmatika, "Pengaruh Penerapan PrinsipPrinsip Good Corporate Governance Terhadap Kinerja Keuangan Perusahaan (Studi pada PT Angkasa Pura II).," Jurnal Akuntansi, vol. 3, no. 2, p. 148-159, 2015.

[8] K. K. \&. D. I. M. A. Dewi, "Pengaruh Penerapan PrinsipPrinsip GCG Pada Kinerja Keuangan Lembaga Perkreditan Desa Kabupaten Gianyar Bali.," E-Jurnal Akuntansi Universitas Udayana, vol. 7, no. 3, p. 559-573., 2014.

[9] C. M. Rambo, "Authority' S Corporate Governance.," vol. 7, no. 3, p. 77-93., 2013.

[10] R. d. K. Utama, "Pengaruh Indikator Good Corporate Governance Dan Profitabilitas Pada Pengungkapan Corporate Social Responsibility.," E-Jurnal Akuntansi, vol. 3, no. 2, p. 368-386, 2013.

[11] e. a. Adebayo, "Good Corporate Governance and Organisational Performance: An Empirical Analysis Adebayo," Bakare Department of Economics Facult, vol. 4, no. 7, p. 170-178, 2014.

[12] e. a. Norwani, "Corporate regulations and quality of financial reporting: A proposed study.," International Journal of Economics and Financial Issues, vol. 6, no. 7, p. 132-136, 2016.

[13] I. P. N. Angayana, "Pengaruh Prinsip - Prinsip Good Governance dan Budaya Organisasi," E-Jurnal Akuntansi Universitas Udayana, vol. 29, no. 1, p. 1984-2000., 2019.

[14] H. Darwis, "Pengaruh Mekanisme Corporate Governance Terhadap Kinerja Perusahaan.," Jurnal Akuntansi Dan Manajemen, STIE YKPN Yogyakarta, vol. 19, no. 3, p. 155172, 2009.

[15] Ben, "Pengaruh Good Corporate Governance Terhadap Kinerja Bank Perkreditan Rakyat Di Kota Bandung.," p. 110., 2015.

[16] D. I. M. A. Renitha, "Pengaruh Penerapan Prinsip-Prinsip Good Corporate Governance Pada Kinerja Bank Perkreditan Rakyat Kabupaten Gianyar.," E-Jurnal Akuntansi, vol. 16, 
no. 1, p. 101-128, 2016.

[17] A. a. H. M. R. Sianggono, "Penerapan Prinsip-Prinsip Good Corporate Governance Pada Perusahaan Keluarga Dalam Industri Mebel.," Jurnal Program Manajemen Bisnis, Program Studi Manajemen, Universitas Kristen Petra, vol. 6, no. 1, pp. 1-6, 2018 